\title{
THE MISAPPROPRIATION OF THE HAKA: ARE THE CURRENT LEGAL PROTECTIONS AROUND MĀTAURANGA MĀORI IN AOTEAROA NEW ZEALAND SUFFICIENT?
}

\author{
Isabella Tekaumārua Wilson*
}

\begin{abstract}
This article analyses the protections the New Zealand intellectual property framework provides for the haka and mātauranga Māori. Part II of this article defines the key terms of "misappropriation", "traditional knowledge" and "mātauranga Māori" in order for the reader to fully understand these concepts in an indigenous, and specifically Māori, context. Part III of this article discusses the importance and significance of haka in Māori culture, particularly looking at the history and significance of Ka Mate, the most well-known haka in New Zealand and the world. Examples of different companies, both New Zealand and internationally-owned, using the haka for commercial benefit are analysed to establish whether or not their use of the haka is misappropriation, and if so, the harm this misappropriation has caused Māori. Part IV discusses the current legal protections New Zealand provides for mātauranga Māori and whether they sufficiently protect the haka and mätauranga Māori generally. It will assess the Haka Ka Mate Attribution Act 2014 as a case study. Part V outlines the limitations of the intellectual framework. Part VI of this article looks to what legal protections would be sufficient to protect against the misappropriation of the haka and mätauranga Māori generally.
\end{abstract}

\section{INTRODUCTION}

Kua tae mai te wa, e whakapuru ai tatou i nga kowhao o te waka.

The time has come where we must plug the holes in the canoe.

* Ngāti Whātua Ōrākei and Waikato-Tainui. 
All over the world, indigenous communities are seeking greater control of their culture. ${ }^{1}$ Māori culture has been suppressed in Aotearoa New Zealand for decades, and now, non-Māori businesses and individuals, in New Zealand and overseas, have begun to exploit Māori culture to promote and enhance their business dealings and sell their products. Typically, these businesses and individuals have no link to Māori culture. For example, when companies from overseas use the haka in an advertisement, it is usually clear that they share no connection to te ao Māori (the Māori world) and no understanding of what the haka means to tangata whenua (people of the land). The haka is a sacred part of Māori culture, it is not something that can be performed for any purpose. In performing a haka, you must uphold the mana (strength and power) of that haka and the kōrero (narrative) woven within it. How can a haka be performed in a way that upholds its mana if the performers do not know the cultural significance of haka or even what the words and actions mean? Those who are ignorant to the sacredness of the haka may use it in exploitative and offensive ways because they do not understand its significance to Māori.

As time has gone on, New Zealanders have become more accepting of Māori culture, embracing its uniqueness and significance. Many non-Māori New Zealanders now see the value in Māori culture and have begun to use aspects of it, such as the haka, in suitable and respectful ways. This type of use is encouraged by Māori. Inappropriate and incorrect use of the haka by individuals or businesses for exploitative means is not.

As the whakatauki given at the start of this article denotes, the time has come where we must plug the holes in the waka. New Zealand's intellectual property system is broken because it is letting mātauranga Māori slip through the gaps of its protection mechanisms. It is time for this to change.

\section{DEFINING KEY TERMS}

\section{A Misappropriation}

The World Intellectual Property Organization (WIPO) Intergovernmental Committee on Intellectual Property and Genetic Resources, Traditional Knowledge and Folklore (WIPO-IGC) defines misappropriation as "any acquisition or appropriation of traditional knowledge by unfair or illicit means". ${ }^{2}$ To define further in a traditional knowledge context, misappropriation means the taking of intellectual property, traditional knowledge, cultural expressions or artefacts from another's

1 Susy Frankel "'Ka Mate Ka Mate' and the Protection of Traditional Knowledge" in Rochelle Cooper Dreyfuss and Jane C Ginsburg (eds) Intellectual Property at the Edge: The Contested Contours of IP (Cambridge University Press, Cambridge, 2014) 193 at 213.

2 Intergovernmental Committee on Intellectual Property and Genetic Resources, Traditional Knowledge and Folklore Protection of Traditional Knowledge: Overview of Policy Objectives and Core Principles WIPO/GRTKF/IC/7/5, 20 August 2004 at 5. 
culture without their consent. This includes the unauthorised use of another culture's dance, dress, music, language, folklore, traditional medicine or religious symbols. ${ }^{3}$

Misappropriation causes the most harm when the source community is a minority group that has been oppressed or exploited in other ways or when the thing being appropriated is exceptionally sensitive. ${ }^{4}$ It hurts Māori to see their culture being misappropriated by the same people who, in the past, suppressed and objected to its use by Māori though both non-legislative and legislative tools such as the Tohunga Suppression Act 1907. In te ao Māori, misappropriation is concerned more with the tapu (sacredness) of the actual thing being appropriated, than with the economic loss suffered. Features of mātauranga Māori, such as the haka, are tapu and hold extreme significance to the iwi (tribe) or hapū (sub-tribe) they affiliate to, and to Māori in general. There is sensitivity surrounding the misappropriation of tapu aspects of mātauranga Māori as any type of use which is not in line with tikanga Māori may result in offence and harm to a Māori community. This harm stems from a tapu object's strong connection to an iwi or hapū, or Māori in general. A tapu item holds mauri, a life force. Therefore, Māori consider these things to be a living and breathing part of their whakapapa. For example, haka carry the stories of iwi through the generations so future members do not forget the triumphs, trials and tribulations of their tupuna (ancestors). Therefore, haka are meant to be treated with respect and used with caution. Any slight misuse of a haka could result in disrespecting the people and community that haka derived from.

\section{B Traditional Knowledge}

Providing one exclusive definition for traditional knowledge is difficult and would be of limited utility due to the vast variety of indigenous communities that use this term to define the "knowledge" within their culture. ${ }^{5}$ WIPO defines traditional knowledge as: ${ }^{6}$

... intellectual activity in a traditional context, and includes the know-how, skills, innovations, practices and learning that form part of traditional knowledge systems, and knowledge embodying traditional lifestyles of indigenous and local communities, or contained in codified knowledge systems passed between generations and continuously developed following any changes in the environment, geographical conditions and other factors. It is not limited to ... any traditional knowledge associated with cultural expressions and genetic resources.

3 At 5 .

4 Rachel Bresnahan "Appropriation vs Appreciation in Music: Where Should We Draw the Line?" (30 June 2016) Sonicbids $<$ http://blog.sonicbids.com>.

5 Frankel, above n 1, at 196.

6 Intergovernmental Committee on Intellectual Property and Genetic Resources, Traditional Knowledge and Folklore The Protection of Traditional Knowledge: Revised Objectives and Principles WIPO/GRTKF/IC/18/5, 10 January 2011 at 18 (emphasis and footnotes omitted). 
The "traditional" aspect of the knowledge stems from its development, maintenance and dissemination amongst traditional communities. ${ }^{7}$ This context is integral to traditional knowledge as it illustrates the need for appropriate protection, which in turn requires sowing respect and recognition for the legal, cultural and social context that applies within an indigenous community. More often than not, the context will involve customary laws and protocols that determine how knowledge and cultural expressions should be maintained and disseminated by the indigenous community. ${ }^{8}$ These customary laws and protocols may not be codified or even expressly articulated in an indigenous community's practices, and may be in oral form as opposed to written. ${ }^{9}$ They may be formally recognised by external legal systems or not currently recognised by the community. They may be connected with other legal systems, including national constitutions, laws and policies. ${ }^{10}$

In acknowledging the difficulty in forming a single definition for traditional knowledge, WIPO conducted nine fact-finding missions from 1998-1999 in 28 countries in the South Pacific, Southern and Eastern Africa, South Asia, North America, Central America, West Africa, the Arab countries, South America and the Caribbean. ${ }^{11}$ Approximately 3000 individuals were interviewed within approximately 60 different cities, towns and villages. ${ }^{12}$ Each mission was reported on separately so to preserve the integrity of the information retrieved from the different regions. ${ }^{13}$ The final report on these fact-finding missions aimed to provide information to WIPO member states, holders of traditional knowledge, the private sector, intergovernmental organisations, academic and research institutions and other interested parties, on the intellectual property needs and expectations of traditional knowledge holders conveyed to WIPO during the missions. ${ }^{14}$

The fact-finding missions made apparent the diverse and dynamic nature of traditional knowledge and highlighted the difficulty in coming up with a singular and exclusive definition of the term, however it was acknowledged that a singular definition may not be necessary in order to define the scope of the subject matter for which protection is being sought. ${ }^{15}$ In the report, WIPO also

7 World Intellectual Property Organization Customary Law, Traditional Knowledge and Intellectual Property: An Outline of the Issues (2013) at 12.

8 At 12.

9 At 12.

10 At 12.

11 At 17.

12 At 19.

13 At 17.

14 World Intellectual Property Organization Intellectual Property Needs and Expectations of Traditional Knowledge Holders: WIPO Report on Fact-finding Missions on Intellectual Property and Traditional Knowledge (1998-1999) (April 2001) at 5.

15 At 26. 
acknowledged that "traditional knowledge" is only a working term and indigenous groups have the right to decide what constitutes their own knowledge, innovations, cultures and practices, and the ways in which they should be defined. ${ }^{16}$

WIPO learnt from the fact-finding missions that traditional knowledge is a rich and diverse source of creativity and innovation. ${ }^{17}$ Furthermore, the missions revealed that indigenous peoples use their traditional knowledge systems as frameworks for continuing creativity and innovation in most areas of technology, ranging from traditional medicinal and agricultural practices to music, design, dance and the graphic and plastic arts. ${ }^{18}$

The protection of traditional knowledge is also imperative for social and cultural reasons. Traditional knowledge plays a role in the economic and social organisation of Aotearoa New Zealand and acknowledging and appreciating the value of such knowledge is a viable means of encouraging and fostering a sense of national unity and identity. ${ }^{19}$

\section{Mātauranga Māori}

Traditional knowledge is the vehicle for mātauranga Māori. Mātauranga Māori encompasses all the traditional concepts of knowledge and knowing that Māori first brought with them to New Zealand and also includes all traditional Māori concepts that have crystallised through the generations. The Waitangi Tribunal in its report Ko Aotearoa Tēnei (Wai 262 report) defined mātauranga in this way: ${ }^{20}$

"Mātauranga" derives from "mātau", the verb "to know". "Mātauranga" can be literally translated as "knowing" or "knowledge". But "mātauranga" encompasses not only what is known but also how it is known - that is, the way of perceiving and understanding the world, and the values or systems of thought that underpin those perceptions. "Mātauranga Māori" therefore refers not only to Māori knowledge, but also to the Māori way of knowing ... Mātauranga Māori incorporates language, whakapapa, technology, systems of law and social control, systems of property and value exchange, forms of expression, and much more. It includes, for example, traditional technology relating to food cultivation, storage, hunting and... it includes arts such as carving, weaving, tā moko (facial and body tattooing), the many performance arts such as haka (ceremonial dance), waiata (song), whaikōrero (formal speech making), karanga (ceremonial calling or chanting), and various rituals and ceremonies ...

16 At 26.

17 At 211

18 At 212 .

19 At 214

20 Waitangi Tribunal Ko Aotearoa Tēnei: A Report into Claims Concerning New Zealand Law and Policy Affecting Māori Culture and Identity - Te Taumata Tuatahi (Wai 262, 2011) [Ko Aotearoa Tēnei: Te Taumata Tuatahi] at 22. 
In the context of mātauranga Māori, haka are not simply dances put on for others entertainment, but rather a means of storytelling and the depositories of the history of iwi and hapū. ${ }^{21}$

\section{Te Tiriti o Waitangi and Mātauranga Māori}

Article 2 of the English text of the Treaty of Waitangi promises to protect Māori in the "full exclusive and undisturbed possession" of their property. ${ }^{22}$ This texts refers to property rights, which does not fit in well with Māori subject matter or the modern context. ${ }^{23}$ Mātauranga Māori, in most circumstances, cannot be exclusively "possessed" as it is a fundamental characteristic of not only mātauranga Māori, but of all knowledge, that it is shared with others. The value and importance of mātauranga Māori derives from its ability to be shared. ${ }^{24}$ Mātauranga Māori involves "products of the hearts and minds of the communities who have created them". 25

Article 2 of Te Tiriti o Waitangi guarantees Māori "te tino rangatiratanga o ... ratou taonga katoa", authority and control over all their treasured things. ${ }^{26}$ Compared to the English text, this wording is more appropriate as it fits with both the Māori subject matter and is consistent with tikanga Māori. ${ }^{27}$ It provides for the sharing of mātauranga Māori, so long as the kaitiaki (guardian) maintains a sufficient authority and control over the sharing. Consequentially, this results in kaitiaki being able to protect the integrity of the mātauranga and control, to some degree, the use and development of it by others. $^{28}$

This Part has outlined key definitions that will be helpful for the reader to understand when considering the remainder of this article. The next section will illustrate the importance of haka, a concept which falls within the realms of traditional knowledge and mātauranga Māori, and the harm that results from its misappropriation.

21 Yasmin Helena Olsen "Whiti Te Rā!: Does the Haka Ka Mate Attribution Act 2014 Signify a Step into the Light for the Protection of Māori Cultural Expressions?" (LLB (Hons) Dissertation, University of Otago, 2015) at 14.

22 Treaty of Waitangi 1840, art 2.

23 Ko Aotearoa Tēnei: Te Taumata Tuatahi, above n 20, at 43.

24 At 43.

25 At $43-44$.

26 Te Tiriti o Waitangi 1840, art 2.

27 Ko Aotearoa Tēnei: Te Taumata Tuatahi, above n 20, at 44.

28 At 44. 


\section{HAKA}

The traditional performing art of haka is an integral part of Māori culture. ${ }^{29}$ Traditionally, haka was a practice of high social significance. ${ }^{30}$ It is an expression of the passion, vigour and identity of the Māori race. ${ }^{31}$ For Māori, haka provides a platform to: ${ }^{32}$

... vent his spleen, to sing someone's praises, to welcome his guests, to open a new meeting house ... to

pay his respects to the dead, to honour his ancestors, to teach his traditions to the succeeding generations.

There are two main types of haka, each used for different occasions. Haka peruperu is a type of war dance and was historically performed before a battle to invoke Tūmatauenga, the god of war. ${ }^{33}$ In haka peruperu, pūkana (widened eyes) and whētero (protruding tongues) are used to psychologically intimidate the enemy. ${ }^{34}$ Haka taparahi is a ceremonial haka and typically comes in short and free form. ${ }^{35}$ Traditionally, it was a posture dance performed by men and women without weapons. ${ }^{36}$ Both forms draw on themes such as kaitiakitanga (guardianship), leadership and social justice. ${ }^{37}$ The powerful and strong gestures involved in a haka are used to daunt an enemy or excite an audience. Haka involves a vigorous use of the diaphragm, commanding movements and loud vocal output which results in tremendous energy and a vivid and clear message directed to the audience. ${ }^{38}$

There have been a number of changes and advances in the haka realm and now haka is considered a significant part of New Zealand culture and society. ${ }^{39}$ This shift can be attributed to the growing acceptance of the place Māori culture has within New Zealand. The emergence of kapa haka festivals and competitions between schools, iwi and other groups has in turn aided in fostering and developing the haka in an authentic and appropriate way. ${ }^{40}$ This has also resulted in an increase in contemporary

29 Whakarewarewa "Maori Cultural Performance" <http://whakarewarewa.com>.

30 Valance Smith "Kapa haka - Māori performing arts" Te Ara - the Encyclopedia of New Zealand (22 October 2014) <http://teara.govt.nz>

31 Audrey Goh "Ka Mate - The Origin" Marimari <www.marimari.com>.

32 Tīmoti Kāretu Haka! Te Tohu o te Whenua Rangatira - The Dance of a Noble People (Reed Publishing, Auckland, 1993) at 87.

33 Ministry of Education "Waiata and haka" <http://eng.kiamau.tki.org.nz>.

34 Smith, above n 30

35 Goh, above n 31.

36 Māori Dictionary "Haka taparahi" < http://maoridictionary.co.nz>.

37 Ministry of Education, above n 33.

38 Smith, above n 30

39 Frankel, above n 1, at 199.

40 Susy Frankel and Megan Richardson "Cultural Property and 'the Public Domain': Case Studies from New Zealand and Australia" in Christoph Antons (ed) Traditional Knowledge, Traditional Cultural Expressions 
haka by modern kapa haka groups. ${ }^{41}$ This shows the developing nature of haka - it is not just a historic art form. ${ }^{42}$ Moreover, there has been a wider acceptance of non-Māori New Zealanders participating in haka performances. ${ }^{43}$ For example, children in New Zealand schools are taught the haka which they use during special events, such as the departure or arrival of new teachers in their schooling journey. ${ }^{44}$ Because of this, those knowledgeable in haka, or haka experts, have taken on a public role in supporting haka performances of others. ${ }^{45}$ These experts have taken up the responsibility of ensuring haka are used correctly and in accordance with tikanga Māori. ${ }^{46}$ They ensure that the customary practices around haka are respected for example around the gender roles of haka, performances by foreigners and commercial uses by New Zealander or overseas companies. ${ }^{47}$

\section{A Ka Mate}

Misuses of the haka, especially Ka Mate, in advertising in New Zealand and overseas has become a major source of contention for not only Māori, but also for those who understand the nature of haka and its place in Māori culture. ${ }^{48}$ The haka "Ka Mate" has been labelled "the most performed, the most maligned, the most abused of all haka". ${ }^{49}$ The contention around Ka Mate has resulted in this haka being the subject of two Waitangi Tribunal disputes and several trade mark related cases which will be discussed later in this article..$^{50}$

Ka Mate gained its notoriety on a global stage due to its sustained performance and marketing by the New Zealand national rugby team, the All Blacks. ${ }^{51}$ The use of Ka Mate by the All Blacks has led to many New Zealanders as well as non-New Zealanders associating Ka Mate with the All Blacks, rather than with its original form, that being a traditional and significant song and dance in Māori

and Intellectual Property Law in the Asia-Pacific Region (Kluwer Law International, Alphen aan den Rijn (The Netherlands), 2009) 275 at 280.

41 At 281.

42 Frankel, above n 1, at 200.

43 Frankel and Richardson, above n 40, at 281.

44 Frankel, above n 1, at 199.

45 Frankel and Richardson, above $\mathrm{n} 40$, at 280

46 At 280 .

47 At 281

48 At 282 .

49 Kāretu, above n 32, at 68.

50 Frankel, above n 1, at 197.

51 Ko Aotearoa Tēnei: Te Taumata Tuatahi, above n 20, at 31 . 
culture. ${ }^{52}$ The All Blacks first used Ka Mate before one of their games in 1905. Originally the All Blacks only performed the haka when they played overseas, however since the 1987 Rugby World Cup they started performing it before every game. ${ }^{53}$ Because of this heavy use by the All Blacks, haka, in particular Ka Mate, has become valued both within New Zealand and around the world. ${ }^{54}$ The frequent use of Ka Mate by the All Blacks adds a level of complexity when considering the inappropriate usage of the haka by non-Māori groups. Can blame be put on businesses for using the haka in an offensive way if they think the haka is simply a dance the All Blacks do before a match, rather than a significant and important aspect of Māori culture that comes with its own tikanga (custom, lore or protocol)? It could be argued that the All Black's use of Ka Mate is aiding in the continuing missapproriation of the haka because their use of Ka Mate is exposing it to a global audience who may not understand its tapu nature. The following section details the origins of Ka Mate, so to illustrate to the reader its extreme significance to Māori and why the misappropriation of it causes harm.

\section{History}

Ka Mate was composed in the 1820 s by Te Rauparaha, a Ngāti Toa rangatira (chief) and descendent of Hoturoa, the captain of the Tainui waka. ${ }^{55}$ This haka was created during a period of conflict between Ngāti Toa and other iwi. ${ }^{56}$ In the midst of this conflict, Te Rauparaha was fleeing an enemy iwi, Ngāti Te Aho, who were seeking retribution for a past wrong Te Rauparaha had committed against them. He sought protection from one of his distant relatives, Te Heuheu of Ngāti Tūwharetoa. ${ }^{57}$ Te Heuheu told Te Rauparaha to go to Lake Rotoaira, the home of Te Wharerangi, a great chief. Knowing that Ngāti Te Aho were fast approaching, Te Wharerangi hid Te Rauparaha in a kumara pit with his wife, Te Rangikoaea, sitting over the entrance in order to hide him, on the advice of Te Wharerangi's tohunga (priest). While this went against tikanga, as males should not put themselves in a position beneath the genitals of a woman, especially a male of senior chieftainship, Te Rauparaha forewent tikanga knowing this was his only chance of survival. ${ }^{58}$

As Ngāti Te Aho arrived at Lake Rotoaira, their own tohunga attempted to locate Te Rauparaha using a karakia (prayer), however the noa (to be free from the extensions of tapu, ordinary,

52 David Murray "Haka Fracas?: The Dialectics of Identity in Discussions of a Contemporary Maori Dance" (2000) 11 TAJA 345 at 346.

53 Frankel, above n 1, at 200.

54 At 197.

55 Ngāti Toa Rangatira "The Origins of Ka Mate" <www.ngatitoa.iwi.nz>.

56 Goh, above n 31.

57 Ko Aotearoa Tēnei: Te Taumata Tuatahi, above n 20, at 29-30.

58 Goh, above n 31. 
unrestricted, void) emitting from Te Rauparaha's wife and the food in the pit hindered the effectiveness of the karakia. ${ }^{59}$ While nervously hiding in the pit, Te Rauparaha muttered "Ka Mate! Ka Mate!" (I die! I die!), but Te Wharerangi told them that Te Rauparaha had gone to Rangipo and so Te Rauparaha, thinking his pursuers were leaving, whispered "Ka Ora! Ka Ora!" (I live! I live!). When the pursuers doubted the words of Te Wharerangi, Te Rauparaha muttered again "Ka Mate! Ka Mate!". However, when Te Wharerangi finally convinced the pursuers that Te Rauparaha was elsewhere and they left, Te Rauparaha emerged from the kumara pit and exclaimed "Ka Ora! Ka Ora! Tēnei te tangata pūhuruhuru, nāna nei i tiki mai whakawhiti te rā!", meaning "I live! I live! For this hairy man who has fetched the sun and caused it to shine again!" The "hairy man" refers to the Te Wharerangi chief who gave Te Rauparaha protection. ${ }^{60}$ Following this, Te Rauparaha, in triumphant celebration performed Ka Mate for Te Wharerangi and his people. ${ }^{61}$

\section{Significance}

The ongoing conflict between Waikato, Ngāti Maniapoto and nearby iwi eventually rendered Ngāti Toa's presence in the area unsustainable and weak. Following this, Te Rauparaha led his iwi's migration to Kapiti Island where Ngāti Toa prospered and was eventually restored to its pre-conflict status. Te Rauparaha is acknowledged as a leader of great mana, who led Ngāti Toa from total defeat to successful conquering of new territories in central Aotearoa. ${ }^{62}$

Te Rauparaha's Ka Mate acts as a symbol of significant change in his iwi's narrative. In coining Ka Mate, Te Rauparaha drew upon the body of knowledge, values and iwi history of the mātuaranga Māori of Ngāti Toa. ${ }^{63}$ The triumph of life over death illustrated in the haka not only applies to Te Rauparaha's successful escape and survival but is also a kōrero on the collective identity, reestablishment and revitalisation of Ngāti Toa as a result of the vision and leadership of Te Rauparaha ${ }^{64} \mathrm{Ka}$ Mate has survived for almost two centuries and remains a taonga (treasure) and source of whakahī (pride) for Ngāti Toa. ${ }^{65} \mathrm{Ka}$ Mate has whakapapa and connects Ngāti Toa to its ancestors. ${ }^{66}$ The haka does not belong to Te Rauparaha, but rather it is a taonga of the Ngāti Toa

59 Olsen, above $\mathrm{n} 21$, at 7

60 Ngāti Toa Rangatira, above n 55.

61 Ngāti Toa Rangatira, above n 55.

62 Olsen, above n 21, at 8 .

63 At 15.

64 At 15.

65 At 7.

66 Ministry of Business, Innovation and Employment Haka Ka Mate Attribution Act 2014 Guidelines at 6. 
people who give life and form to the words. ${ }^{67}$ The combination of whakapapa and kōrero in taonga give it mauri. Mauri is the spark of life. ${ }^{68}$ Even after Te Rauparaha's death, Ka Mate continued in importance and significance to Ngāti Toa, as they consider themselves the kaitiaki of that haka. It is their heritage and taonga to protect and preserve for the future generations. ${ }^{69}$ Without the kaitiaki, Ka Mate and other haka alike risk being lost in history.

\section{B Misappropriation Examples}

As the trading of goods between countries develops and increases, so too has the tradability of intellectual property. ${ }^{70}$ However, the tradability of traditional knowledge has seemingly been tacked on to this process even though traditional knowledge is not recognised on a national and international scale as having the same legal status of traditional intellectual property. ${ }^{71}$ Companies, overseas and in New Zealand, have therefore extracted value from Māori culture in their efforts to advertise and sell their products. ${ }^{72}$ This article outlines four examples from the companies or enterprises Fiat, Heineken, the Bakery Industry Association of New Zealand and The Fate of the Furious (Fast and Furious 8) and analyses their usage of the haka in order to determine whether their application of the haka for advertising or commercial purposes is appropriate.

\section{Fiat advertisement}

In 2006, an Italian commercial aired which used a haka to promote a new car. It involves a group of women, dressed in black, on a public street standing beside a Fiat Idea, imitating the words and actions of Ka Mate. Crowd noises are playing in the background throughout the advertisement in an attempt to replicate the atmosphere of a New Zealand rugby match. One woman then gets into the car and drives off, looking to her backseat and smiling at her son who then pokes out his tongue, mimicking a pūkana. ${ }^{73}$

When the New Zealand Ministry of Foreign Affairs and Trade (MFAT) became aware that an Italian advertising company was planning on using the haka, it advised the company that the use of Ka Mate in this was "culturally insensitive and inappropriate". ${ }^{74}$ After consulting the Ministry of

67 Haka Ka Mate Attribution Act 2014, sch

68 Olsen, above n 21, at 15 .

69 Frankel, above n 1, at 198.

70 At 194

71 At 194

72 At 195 .

73 New Zealand Press Association "Italians drive ahead with Car Mate haka [video clip]" The New Zealand Herald (online ed, Auckland, 4 July 2006).

74 New Zealand Press Association, above n 73. 
Culture and Heritage and Toi Māori Aotearoa (Māori Arts New Zealand), MFAT further advised the company that it should be using a Māori group to perform the haka or at the very least use a haka that was composed for women as Ka Mate is not a female-led haka. The company proceeded with the advertisement despite this advice. No further action by the New Zealand government was taken. ${ }^{75}$

This advertisement constitutes a misappropriation in a number of ways. The advertising company did not consult with Māori in the planning of this advertisement nor did it ask for permission to use the haka. ${ }^{76}$ When consultation and advice was offered, the company did not take it. This advertisement was used to sell motor vehicles, however no recompense was given to Māori in any way. ${ }^{77}$ The advertisement comes across as humorous, this being reinforced by the little boy poking his tongue out at the end and the crowd noises playing in the background. The haka is not meant to be used in humorous situations. The haka is a powerful expression of Māori culture and when performing a haka, individuals should remain serious and staunch to reflect the mood of the haka. Furthermore, the haka that was used is not meant to be performed by women. While haka can be written for women or incorporate women, the one used in this advertisement was not. ${ }^{78}$ The women in the advertisement are not saying the right kupu (words), nor are they performing the right ā-ringa (actions). This shows a total disrespect for Ka Mate and the history behind it. When the women in the advertisement perform the haka, their actions and words are empty and meaningless. This should never be the case when a haka is performed.

\section{Heineken advertisement}

Heineken were the sponsor for the Rugby World Cup 2015. It put out an advertisement which involved unsuspecting customers in a supermarket in Ireland being surprised by a group of three Māori males performing a haka. When the group jump into the open to perform a haka, many of the customers scream and move away, most looked shocked, while some are seen laughing. The three males then signal to the customers to perform a haka of their own. The two customers who performed the best then flipped a coin to decide who would win tickets to the Rugby World Cup final. ${ }^{79}$

Like the Fiat commercial, this advertisement attempts to portray a humorous narrative. Those who are instructing the customers on what to do through a speaker in the supermarket are laughing throughout the advertisement. Most, if not all, of the customers who are trying to perform a haka clearly have no idea what they are doing and are also laughing. None of the customers know the

75 Frankel, above n 1, at 212.

76 At 197.

77 At 197

78 At 197

79 Katie Kenny "Heineken the latest company to mock the haka for profits" (24 September 2015) Stuff <www.stuff.co.nz>. 
correct kupu and à-ringa. Two of the female customers poke their tongues out at the end which goes against tikanga, as when woman pūkana they are meant to keep their mouth closed.

There are two aspects of concern when considering this advertisement: firstly, the customers who attempt a haka in response to the three Māori men and secondly, the three Māori men who perform the initial haka. While the men are Māori and are performing the haka correctly in terms of kupu and à-ringa, is what they are doing misappropriation considering the context of their haka, that being for an advertisement for beer for commercial gain? It could be argued that the narrative embedded in the haka being performed by these men is shown disrespect by the context of this advertisement therefore they are misappropriating the haka being performed. ${ }^{80}$

\section{Bakery Industry Association of New Zealand advertisement}

This advertisement was created by the Bakery Industry Association of New Zealand (BIANZ) to promote the Bakery of the Year Awards. ${ }^{81}$ The advertisement entails a group of cartoon gingerbread men performing Ka Mate in an oven. At the end of the haka a bag of white flour drops down on the gingerbread men and crushes them. The words "The Challenge is on! Vote for your favourite bakery now and be in to win a $\$ 500$ travel voucher" appear on the screen.

Arguably, the gingerbread men are saying the correct kupu and performing the correct à-ringa, however, this advertisement still raises a lot of concerns. Like the advertisements discussed above, the narrative of this advertisement is comedic and could be interpreted as mocking the haka. The individuals doing the haka in this advertisement are cartoon gingerbread men. Their voices have been altered to be a very high pitch. At a point in the advertisement a chocolate button falls off one of the gingerbread men. The scene of the white flour crushing the brown haka-performing gingerbread men is also concerning. One could argue it depicts, albeit unintentionally, the cruel history and effects of colonisation on the Māori people. The advertisement ends with one of the gingerbread men making a throat-slitting action and doing the pūkana. ${ }^{82}$ This does not come across as threatening and powerful, it is clear BIANZ put it at the end for comedic purposes.

BIANZ did not consult with Māori in creating the advertisement. ${ }^{83}$ When a spokesperson from Awataha Marae expressed their concerns over the advertisement, the executive officer of BIANZ responded by saying they did not think their advertisement was culturally insensitive and that they took all appropriate steps to ensure that their advertisement would not cause offence. ${ }^{84}$ Those steps

80 Michael Neilson "Misuse of haka Ka Mate 'tramples' on mana, call for greater protection in New Zealand and overseas" The New Zealand Herald (online ed, Auckland, 11 February 2019).

81 "Gingerbread haka causes upset" North Shore Times (online ed, Auckland, 31 January 2009).

82 "Gingerbread Man Haka" (19 July 2007) YouTube <www.youtube.com>.

83 "Gingerbread haka causes upset", above n 81.

84 "Gingerbread haka causes upset", above n 81. 
involved ensuring the exact words of Ka Mate were used to "maintain the integrity of it". ${ }^{85}$ However, it is not enough to say that the words were correctly used, there must be a strong connection between the haka and those performing it. As the spokesperson from Awataha Marae commented: "there's an obvious disconnection between the haka and gingerbread men". 86

The fact that this was a New Zealand-made advertisement targeted at a New Zealand audience also raises questions and concerns. Should this advertisement not be considered misappropriation because New Zealanders made the advertisement and so have a connection to Māori culture, or is it worse as they are New Zealanders and so should have known better than to use the haka in this context? The answer should be the latter. The majority of the members of BIANZ who were involved in the writing and producing of this advertisement are New Zealanders and would have grown up surrounded by, or at the very least aware of, Māori culture. At the very least, they should have known better than to use Ka Mate in their advertisement, with the aim of promoting their competition in a comedic way, without meaningful consultation with Māori. If Māori were consulted during the creation of this advertisement there is no doubt they would have concluded that BIANZ had used Ka Mate in an inappropriate way.

\section{Fast and Furious 8: The football scene}

This scene in Fast and Furious 8 begins with Dwayne "The Rock" Johnson in his role as Luke Hobbs giving a pep talk. The talk is serious and implies that a battle or fight is about to begin. The camera cuts to those who are receiving this pep talk; it is a group of young girls who are about to play a football game and Luke Hobbs is their coach. As the referee blows his whistle to signal the commencement of the game, the girls and Luke Hobbs get into formation and perform a haka to the opposing team. The music playing in the background is intense and war-like. As the camera pans the girls on the opposing team, they all look a combination of scared, intimidated and confused. When the haka ends, the girls in the opposing team run off, apart from one who then says "I don't want to play anymore". 87

Out of all the examples discussed above, the use of the haka in Fast and Furious 8 is the closest to walking the line on whether it is misappropriation or not. This example illustrates the difficulty in setting the boundaries around what is offensive or simply "appropriate cultural mixing". ${ }^{8}$ No one in the cast or crew who took part in the making and performing of the haka was Māori. The choreographer of the haka in this movie was Layne Hannemann, a cultural advisor of American

85 "Gingerbread haka causes upset", above n 81.

86 "Gingerbread haka causes upset", above n 81.

87 The Audio Guy "fast and furious 8 Dwayne Johnson entry Haka dance by the rock" (4 July 2017) YouTube <www.youtube.com>.

88 Ko Aotearoa Tēnei: Te Taumata Tuatahi, above n 20, at 41. 
Samoan descent. ${ }^{89}$ However, during an interview, Johnson said that the dance was curated by the movie's choreographer and later blessed by Māori elders. ${ }^{90}$

On his twitter account, Johnson tweeted a video of the scene and described the dance as "very meaningful in our Polynesian culture". ${ }^{91}$ In an Instagram post, Johnson talks about this haka scene, he wrote: ${ }^{92}$

... credit to these fierce young girls who for weeks and weeks practiced our HAKA and embedded it in their DNA. They understood the meaning behind every word and every warrior gesture. That's why at the top of this vid[eo] when I yell "KIA RI TE" they go from happy and clapping to emotionally allowing their MANA to take over them ...

Johnson went on to say "[the haka is 100 per cent] the most REAL and AUTHENTIC scene in the movie. No acting. Just from our hearts and WARRIOR MANA (warrior spirit)".93

For this use of the haka, it seems like the processes Johnson and the film crew went through were thorough and correct. They wrote their own haka as opposed to taking a haka from a Māori group, and then consulted with Māori on the appropriateness and correctness of the haka they created. Johnson and the young girls performing the haka knew the kupu and the ā-ringa, but more importantly they knew the meaning behind them. At the end of the haka, Johnson does a male pūkana, poking his tongue out, and the young girls do a female pūkana, with their mouths closed and eyes widened. When comparing to the other examples above where some females were poking their tongues out in their attempt of a pūkana, this shot of the pūkana show that they all knew the tikanga around not poking your tongue out if you are a female.

While it can be argued this haka was used for commercial gain as it was used to enhance a scene of the movie by making it more entertaining for viewers, it also could be argued that Johnson and the producers' main purpose for putting a haka scene in the movie was to pay respect towards a "warrior" culture to which Johnson, who is of Samoan descent, has some connection, as a member of the Polynesian race. Although no one who performed the haka in this movie was Māori, being Māori is not a criteria for a non-misappropriated haka. On balance, the performance of the haka in Fast and Furious 8 was not a misappropriation.

89 Layne Hannemann (@lthannemann) (16 July 2019) Instagram <www.instagram.com/p/Bz9Ati_HDIh>.

90 "Dwayne 'The Rock' Johnson performs haka in upcoming Fast and Furious movie" (6 August 2016) Stuff <www.stuff.co.nz>.

91 "Dwayne 'The Rock' Johnson performs haka in upcoming Fast and Furious movie", above n 90.

92 Dwayne Johnson (@ therock) (6 August 2016) Instagram <www.instagram.com/p/BIu-ne-j5aT>.

93 Johnson, above n 92. See also "Video: Dwayne 'The Rock' Johnson's Fate of the Furious haka" (24 March 2017) Newshub <www.newshub.co.nz>. 


\section{Common Themes of Misappropriation}

In analysing the above examples, many common themes of misappropriation arise. These themes consist of incorrect use of words and actions, misused gender roles, comedic undertones and no attribution or resulting commercial profit for Māori. All of these consequences arising from companies misusing mātauranga Māori, more specifically the haka, result in harm for Māori. The Fiat, BIANZ and Heineken advertisements incorrectly portray the haka as a funny dance that anyone can perform. This article does not assert that all of these companies are misappropriating mātauranga Māori on purpose, but rather it is their ignorance of mātauranga Māori that is causing harm to Māori. Regardless of whether the intent is innocent ignorance or malicious, harm still occurs. However it could be argued that the company that created the Fiat advertisement did misappropriate the haka with malicious intent. It was told by the New Zealand Government not to release the advertisement as it stood but it ignored the advice and nevertheless released the advertisement. It could be argued that this shows a clear disregard and disrespect for Māori and Māori culture.

Different haka are taonga to the iwi they affiliate to. When Māori see their haka being used in a comedic setting with inaccurate words, actions and gender roles it causes them mamae (hurt), as that haka is part of their whakapapa. When a company disrespects an iwi's haka, they are showing disrespect to the iwi themselves. Moreover, they are making a profit from it. Tangata Māori (Māori people) can feel mamae even if it is not their own haka being misappropriated as all Māori have felt the effects of the suppression of their culture and it hurts to see their culture being used by those who took it away from them and who now reap commercial benefits.

\section{Any Publicity is Good Publicity?}

There has been a lot of public discussion within New Zealand and internationally around whether the use of the haka in advertisements and movies, especially those filmed and shown overseas, constitutes misappropriation. Some see it as appreciation of New Zealand and Māori culture. The use of haka in global media promotes and publicises Māori culture by exposing it to a huge international audience. This line of reasoning asserts that Māori should be happy that their culture is being shared and enjoyed by an international audience. By putting the haka on a global stage more people will experience it, like what they see and want to come to New Zealand to experience the haka in the country it originated from. This in turn increases tourism and boosts the New Zealand and Māori economies. This argument follows that traditional culture and aspects of it, such as the haka, should be able to be used and shared by anyone as it is a public resource that is in the public domain and cannot be the subject of property rights. ${ }^{94}$ Moreover, some may see the desire of Māori to control the use of their haka and culture as an attempt to close off or "repatriate" it from the public domain. .5

94 Ko Aotearoa Tènei: Te Taumata Tuatahi, above n 20, at 40.

95 At 40. 
However, it could also be argued that giving free and unfettered public access to resources may not always serve the public good, especially when it comes to public access to traditional knowledge. ${ }^{96}$ This argument is explored below.

\section{Kaitiaki relationship}

Māori are not only concerned with protecting an individual sign, symbol, story, song, artwork or tradition such as the haka. Māori are also concerned with the protection of the knowledge and cultural, spiritual and other significance that things in their culture convey and carry. ${ }^{97}$ Overall, the main priority of Māori is maintaining their kaitiakitanga (guardianship) over their culture and traditions as a whole. ${ }^{98}$

Marsden and Henare define kaitiakitanga in the following way: ${ }^{99}$

The term "tiaki" whilst its basic meaning is "to guard" has other closely related meanings depending on the context. Tiaki may therefore also mean to keep, to preserve, to conserve, to foster, to protect, to shelter, to keep watch over. The prefix "kai" denotes the agent of the act. A "kaitiaki" is a guardian, keeper, preserver, conservator, foster-parent, protector. The suffix "tanga" added to the noun means guardianship, preservation, conservation, fostering, protecting.

Kaitiaki have perpetual relationships with taonga works. ${ }^{100}$ When looking at the taonga Ka Mate, as long as this haka continues to exist, so too will the kaitiaki obligations of Ngāti Toa Rangatira. ${ }^{101}$ The main desire of kaitiaki is to protect and safeguard the integrity and mauri of their taonga works, as well as the mātauranga Māori that sits beneath it. 102 "Taonga work" is a term the Waitangi Tribunal created to define: ${ }^{103}$

... a work, whether or not is has been fixed, that is in its entirety an expression of mātauranga Māori; it will relate to or invoke ancestral connections (whakapapa), and contain or reflect traditional narratives or stories.

96 Frankel and Richardson, above n 40, at 276.

97 At 278 .

98 At 278

99 Māori Marsden and TA Henare Kaitiakitanga: A Definitive Introduction to the Holistic World View of the Māori (Ministry for the Environment, Wellington, 1992) at 18.

100 Ko Aotearoa Tènei: Te Taumata Tuatahi, above n 20, at 39

101 Ministry of Business, Innovation and Employment, above n 66, at 6.

102 Ko Aotearoa Tènei: Te Taumata Tuatahi, above n 20, at 39; and Ministry of Business, Innovation and Employment, above n 66, at 6.

103 Ko Aotearoa Tēnei: Te Taumata Tuatahi, above n 20, at 54. 
This definition is used to distinguish taonga works from other works, known as taonga-derived works, which the Waitangi Tribunal described as: 104

... a work that derives its inspiration from mātauranga Māori or a taonga work, but does not relate to or invoke ancestral connections (whakapapa), nor contain or reflect tradition narratives or stories in any direct way. A taonga-derived work is identifiably Māori in nature, but has neither mauri nor living kaitiaki $\ldots$

Under New Zealand law, there are discrepancies between the obligations of kaitiaki in respect of their taonga works and mātauranga Māori, and the requirements and limitations of New Zealand's intellectual property law system. ${ }^{105}$ There are wide disparities between the protections being sought by kaitiaki in respect of their taonga works and mātauranga Māori and the protections that are offered by trade mark and copyright law. ${ }^{106}$ Taonga works are "products of the hearts and minds of the communities who have created them". ${ }^{107}$ They cannot be compared to land or other physical resources where there is value in exclusively possessing them. ${ }^{108}$

For a long time, kaitiaki have asked for a legal regime that protects their taonga works from offensive and inappropriate usage. While the Crown has done some work in this area, kaitiaki are calling for the legal protections over their taonga works to be strengthened and broadened. ${ }^{109}$ From the kaitiaki relationship, which involves the protection of culture and traditions, flows the consequential benefits of encouragement of creativity and innovation within te ao Māori. Once a kaitiaki relationship can be established between a Māori group, or Māori in general, and a taonga work, such as a haka, the choice to benefit commercially from the use of their own cultural creations should be the choice of the kaitiaki. ${ }^{110}$ Looking specifically to Ka Mate, Ngāti Toa are considered, both in tikanga and New Zealand law, its kaitiaki for future generations and so the benefit extends beyond the existing beneficiaries. ${ }^{111}$

Kaitiaki, and Māori generally, accept and acknowledge that all cultures require growth and development in order to survive and thrive. ${ }^{112}$ Māori, Māori culture and New Zealanders in general

104 At 56.

105 At 33 .

106 At 39 .

107 At $43-44$.

108 At 43.

109 At 39.

110 At 39.

111 Frankel, above n 1, at 207; and Haka Ka Mate Attribution Act.

112 Ko Aotearoa Tēnei: Te Taumata Tuatahi, above n 20, at 40. 
gain a lot from the development of new taonga works and uses of mātauranga Māori. However the existence of taonga works and mātauranga Māori in the public domain cannot and should not entitle others to use those taonga works and mātauranga Māori in any way they want. ${ }^{113}$ Currently, nonkaitiaki, both within and outside of New Zealand, are able to acquire the rights to a lot of taonga works and mātauranga Māori without the consent of, or providing any benefit to, kaitiaki. ${ }^{114}$ Non-Māori parties are able to use taonga works and mātauranga Māori and then acquire private property rights in them. These parties are even able to prohibit kaitiaki from using these works without permission. ${ }^{115}$ While it is accepted that there is a public interest in free access to material that is in the public domain, that interest should be subjected to Treaty requirements and the right of the kaitiaki should prevail over the public interest in certain circumstances, for example where the public use of mâtauranga Māori is offensive and derogatory. ${ }^{116}$ At a minimum, businesses should not be allowed to exploit and misappropriate mātauranga Māori without meaningful engagement and consultation with the relevant kaitiaki. ${ }^{117}$

Māori and kaitiaki do not want all uses of mātauranga Māori by non-Māori to be prohibited. Noncommercial public uses of the haka, that are not offensive or do not amount to misappropriation, should be encouraged. For example, the performance of waiata and haka in schools ${ }^{118}$ or in the workplace promotes and celebrates the use of mātauranga Māori, which is a positive step towards a society that fully accepts and embraces Māori culture. This is what kaitiaki want: to share and celebrate their taonga with all New Zealanders in a respectful and meaningful way.

As illustrated in the examples above, the haka is vulnerable to misappropriation on a global scale. There is little kaitiaki can do about this due to the lack of legal protection New Zealand offers mātauranga Māori. The next section will look at the current laws, or lack thereof, New Zealand has in protecting the haka and mātauranga Māori.

\section{CURRENT PROTECTIONS IN NEW ZEALAND}

\section{A New Zealand Laws Protecting Mātauranga Māori}

Internationally, New Zealand is recognised as a pioneer in the indigenous intellectual property arena and states look to New Zealand for guidance in protecting their own indigenous cultural

113 At 40

114 At $39-40$.

115 At 40 .

116 At 50

117 At 50.

118 At 50. 
heritage. ${ }^{119}$ The government's scheme for economic development in the Māori business arena is called He kai kei aku ringa, the Crown-Māori Economic Development Strategy. ${ }^{120}$ The Intellectual Property Office of New Zealand (IPONZ) acknowledges the unique and distinct social and cultural significance of mātauranga Māori, and provides for He kai kei aku ringa by aiding and supporting Māori businesses, communities and organisations in recognising, managing and protecting their intellectual property. ${ }^{121}$ For example, IPONZ helps Māori individuals, businesses and organisations identify elements of Māori culture that offer unique branding and marketing opportunities and commercial value that can be protected through intellectual property rights. ${ }^{122}$ In turn, these intellectual property rights can help Māori regulate and restrict the commercial use of mātauranga Māori to ensure that it is acknowledged and respected. ${ }^{123}$

New Zealand's intellectual property laws are internationally recognised for establishing Māori Advisory Committees. These committees are tasked with minimising the possibility of the Crown registering intellectual property which causes offence to Māori. ${ }^{124}$ There are two committees, the Trade Marks Māori Advisory Committee and the Patents Māori Advisory Committee. To be a member on these committees an individual must have a strong understanding of mātauranga Māori and tikanga Māori. ${ }^{125}$ These committees advise the Commissioner of Patents, Trade Marks, Designs and Plant Variety Rights on whether the registration of a trade mark or design, or the granting of a patent that includes a Māori cultural element would be offensive to Māori, and whether commercial exploitation of an invention in the producing, marketing and sales processes would be contrary to Māori values. ${ }^{126}$ A Māori cultural element is a characteristic of intellectual property that displays, or is taken from, mātauranga Māori. ${ }^{127}$ A Māori cultural element could be a Māori word, a Māori design, an indigenous plant or bird, or Māori music or dance. ${ }^{128}$ It could contain only a small part of the intellectual property such as the use of a Māori word on a product with no connection to Māori culture, or it could involve

119 New Zealand Intellectual Property Office Protecting intellectual property with a Māori cultural element: User Guide (Ministry of Business, Innovation and Employment, June 2016) at 1.

120 At 1.

121 At 1 .

122 At 3 .

123 At 3 .

124 New Zealand Intellectual Property Office "Māori Advisory Committees" Ministry of Business, Innovation and Employment <www.iponz.govt.nz>.

125 New Zealand Intellectual Property Office, above n 124.

126 New Zealand Intellectual Property Office, above n 119, at 1.

127 At 3 .

128 At 3. 
the entirety of the intellectual property, such as a recording of a Māori song or dance. ${ }^{129}$ These cultural considerations are important as particular Māori words, expressions, performances, images and places may have social, cultural and spiritual significance for Māori. ${ }^{130}$ There are a lot of circumstances where it would not be appropriate to use a Māori cultural element in a product, ${ }^{131}$ for example, giving a beer with no connection to mātauranga Māori a Māori name. Even well-known Māori words and designs should be treated with caution as while they may be familiar to the general New Zealand public, they may hold special significance to Māori and so merit special consideration and respect. ${ }^{132}$ The haka Ka Mate is an example of a well-known Māori construct that also holds significant meaning to Māori, particularly Ngāti Toa Rangatira.

The Commissioner makes the final decision on whether a trade mark or patent with a Māori cultural element can be registered. ${ }^{133}$ While the Commissioner must consider the advice given by the Committees, they are not required to follow it. ${ }^{134}$ Alongside the advice the Māori Advisory Committees provide, the Commissioner will also consider other relevant factors to determine whether the trade mark, design or patent can be registered or granted. ${ }^{135}$

\section{The Government's recent response to Wai 262 claim and report}

In August 2019 the Minister for Māori Development, Hon Nanaia Mahuta, announced at the National Iwi Chairs Forum that the New Zealand Government was in the process of developing a whole of government approach, named Te Pae Tawhiti, to address the issues and concerns raised in the Waitangi Tribunal's Wai 262 report. Prior to this, the Crown had not made a formal response to Wai 262 and the issues it identified, nor had the Crown made efforts to consult with the Wai 262 claimants and Māori generally in regards to the steps the Crown should be taking to address the lack of legal protection for mātauranga Māori in the intellectual property sphere. ${ }^{136}$

Te Pae Tawhiti proposed to establish three ministerial kete, or groups: Taonga works me te Mātauranga Māori, Taonga species me te Mātauranga Māori and Kawenata Aorere/Kaupapa

129 At 3 .

130 At 9.

131 At 9 .

132 At 10.

133 At 6.

134 At 6.

135 At 6.

136 Cabinet Minute of Decision "Developing a Whole-of-Government Strategy for WAI 262" (10 April 2019) CAB-19-MIN-0138.01 at [3]. 
Aorere. ${ }^{137}$ These groups will be overseen by a ministerial oversight group to ensure the issues presented by the Wai 262 report are given due weight across government. ${ }^{138}$ The kete relevant to this article is Taonga works me te mātauranga Māori. The scope of this kete includes looking at how to empower kaitiaki to fully exercise kaitiakitanga over taonga works and mātauranga Māori, defining the Crown's role in respect of taonga works and mātauranga Māori and determining whether a new legal framework is needed to sufficiently protect taonga works and mātauranga. ${ }^{139}$ The legislation this kete plans to review includes the Copyright Act 1994 and the Haka Ka Mate Attribution Act $2014 .{ }^{140}$

The primary purpose of Te Pae Tawhiti will be to facilitate and support kanohi ki te kanohi (face to face) discussions during September and October of 2019 with targeted Māori groups, such as the Wai 262 claimants, Māori technical experts, iwi leaders and various national Māori bodies, about the proposals the Crown put forward in the document. ${ }^{141}$ These discussions will help shape the government's approach going forward in addressing the issues outlined in the Wai 262 claim and report.

After 30 years of silence from the Crown on the issues identified by the Wai 262 report, Te Pae Tawhiti is a welcomed and promising step forward in providing adequate protection for mātauranga Māori. Time will tell whether Te Pae Tawhiti and the mahi (work) that follows will improve the legal protections over mātauranga Māori in New Zealand and overseas.

After considering Te Pae Tawhiti and the laws that attempt to protect mātauranga Māori in general, this article will now look to the law in New Zealand that offers protection over the haka, that being the Haka Ka Mate Attribution Act.

\section{B New Zealand Laws Protecting the Haka}

New Zealand law explicitly protects two objects within mātauranga Māori: Ngāi Tahu's relationship with pounamu and the haka Ka Mate. ${ }^{142}$

137 Ministry of Māori Development Te Puni Kōkiri Wai 262 - Te Pae Tawhiti: The role of the Crown and Māori in making decisions about taonga and mätauranga Mãori-Preliminary proposals for Crown organisation (August 2019) at 13.

138 At 16.

139 At 20.

140 At 20 .

141 At 25. This article was written before consultation took place: see Te Puni Kōkiri Wai 262 - Te Pae Tawhiti: Targeted Engagement Report - Preliminary proposals for Crown Organisation (2020).

142 New Zealand Intellectual Property Office, above n 119, at 10. 
In Ngāti Toa's deed of settlement, signed in 2012, the Crown recognised Ngāti Toa Rangatira's unique cultural and spiritual connection with Ka Mate. ${ }^{143}$ The Crown also acknowledged the signficance and importance of Ka Mate as a taonga of Ngāti Toa Rangatira and as an integral part of their history, culture and identity. ${ }^{144}$ Finally, in the deed the Crown recognised Ngāti Toa Rangatira's perpetual role as kaitiaki and their unassignable right of attribution in relation to Ka Mate. ${ }^{145}$ It follows that any individual who publishes, broadcasts or shows, publicly, a film featuring Ka Mate must attribute it to Te Rauparaha and Ngāti Toa Rangatira. ${ }^{146}$ The Haka Ka Mate Attribution Act gives effect to the provisions in the deed between the Crown and Ngāti Toa concerning the haka Ka Mate. ${ }^{147}$

The Ka Mate Attribution Act is the first of its kind in New Zealand, being the first case of intellectual property protection of an iwi's taonga to arise out of Treaty settlement negotiations. ${ }^{148}$ The Act gives meaningful recognition and acknowledgement to the mana of the haka and provides Ngāti Toa Rangatira with recognition of their cultural connection with Ka Mate by ensuring that whenever this haka is used, the original creator of the haka is acknowledged. ${ }^{149}$

The Act requires individuals who use the words or associated actions of Ka Mate, or any part of Ka Mate, in any publication for commercial purposes, any public communication or in any film that is shown publicly, to pay attribution to Te Rauparaha and Ngāti Toa Rangatira. ${ }^{150}$ Adequate attribution requires a statement acknowledging Te Rauparaha as the composer of Ka Mate and a chief of Ngāti Toa Rangatira. ${ }^{151}$ The statement must be clear and prominent and must be likely to bring Te Rauparaha's identity as the composer of Ka Mate and a chief of Ngāti Toa Rangatira to the viewer or listener's attention. ${ }^{152}$ In some circumstances no attribution is required. These circumstances include any performance of Ka Mate, any use of Ka Mate for educational purposes, anything made for the purpose of criticism, review, or reporting current events, or any communication of Ka Mate to the

143 Ngati Toa Rangatira and Toa Rangatira Trust and the Crown Deed of Settlement of Historical Claims (2012) at 89 .

144 Ministry of Business, Innovation and Employment, above n 66, at 6.

145 At 6.

146 New Zealand Intellectual Property Office, above n 119, at 32.

147 At 6.

148 Lynell Tuffery Huria "The Haka Ka Mate Attribution Act: The right of attribution" (7 May 2014) AJ Park <www.ajpark.com>.

149 Ministry of Business, Innovation and Employment, above n 66, at 2.

150 Haka Ka Mate Attribution Act, s 10(1)

151 Ministry of Business, Innovation and Employment, above n 66, at 7.

152 Haka Ka Mate Attribution Act, s 9(4)(a) and (b). 
public for a purpose that is not commercial. ${ }^{153}$ If an individual using Ka Mate does not attribute appropriately when required, Ngāti Toa Rangatira holds the right to obtain a court declaration stating a failure to comply with the Haka Ka Mate Attribution Act, and ordering for the individual to comply. ${ }^{154}$ In these circumstances, the court is able to make an award to Ngāti Toa Rangatira towards their costs for legal proceedings. ${ }^{155}$

The New Zealand operatic trio Sol3 Mio was the first group who used a statement of attribution in regards to Ka Mate. ${ }^{156}$ Sol3 Mio performed a rendition of "I See Fire" by Ed Sheeran for the All Blacks' Rugby World Cup campaign 2015. ${ }^{157}$ Snippets of Ka Mate were used in their version. For the last 10 seconds of the music video the words "Ka Mate - This haka was composed by Te Rauparaha a chief of the iwi/tribe $\mathrm{Ng}[\bar{a}]$ ti Toa Rangatira and has been used with the permission of Te Runanga o Toa Rangatira" appeared on the screen. ${ }^{158}$ Obtaining permission from Ngāti Toa Rangatira to use Ka Mate is not a requirement under the Act which simply requires an acknowledgement of Te Rauparaha and Ngâti Toa Rangatira. Sol3 Mio's statement therefore was enough to satify the requirements under s 9 .

\section{LIMITATIONS}

\section{A Haka Ka Mate Attribution Act}

While the Haka Ka Mate Attribution Act is a landmark piece of legislation, it does have its limitations. One of biggest limitations of Act is that its enforcement is limited to New Zealand, therefore overseas businesses and companies are able to use Ka Mate for commercial and promotional purposes without acknowledging Te Rauparaha and Ngāti Toa Rangatira. While Ka Mate has no international protection, one would think that the national significance and importance of Ka Mate to New Zealanders and the existence of the Act would deter companies from using Ka Mate innappropriately. However instances such as the Heineken advertisements show that this is not the case. $^{159}$

While this legislation allows for the recovery of court costs by Ngāti Toa in situations where an individual has used Ka Mate but not attributed appropriately, the Act does not provide for the award

153 Haka Ka Mate Attribution Act, s 10(2).

154 Ministry of Business, Innovation and Employment, above n 66, at 9.

155 At 9 .

156 Olsen, above n 21, at 29.

157 At 29.

158 SOL3 MIO " Sol3 Mio - I See Fire" (3 September 2015) YouTube <www.youtube.com>.

159 Olsen, above n 21, at 33 . 
of damages to Ngāti Toa for a failure to attribute nor does it allow for an injunction for a breach. ${ }^{160}$ Furthermore, the redress provided for in the Act does not allow for Ngâti Toa to claim royalties or compensation for the commercial use of Ka Mate. ${ }^{161}$ The remedial declaratory judgement has limited benefits for Ngāti Toa as by the time legal action is taken, the party will have already used Ka Mate without attribution and the damage will have been done. ${ }^{162}$ The guilty party will most likely not face any public backlash as there is no requirement for the declaration of breach to be made publicly known. ${ }^{163}$ Moreover, there is a risk that Ngāti Toa will lose money through enforcing their rights under the Act as the court costs awarded are based on the conduct of the litigation, rather than on the merits of the case and the seriousness of the breach, and will most likely not cover the actual costs of bringing a claim forward. ${ }^{164}$ This highlights Ngāti Toa's right of attribution as more of a cultural right as opposed to an economic right. ${ }^{165}$

The attribution requirements within the Act are not onerous or difficult to obey. ${ }^{166}$ The requirements are influenced by the moral rights provisions found in the Copyright Act, but they are not legislated within the Copyright Act. ${ }^{167}$ This illustrates the intention of the Crown to balance redress for claimants with the public interest and New Zealand's intellectual property framework. ${ }^{168}$ In turn this results in weaker redress for Ngāti Toa.

Ka Mate is used by a variety of people in a range of commercial and non-commercial situations. The deed and the Act therefore do not recognise exclusive ownership rights in Ka Mate which would prevent its use by other parties. ${ }^{169}$ From 1998-2006 Te Runānga O Toa Rangatira, a trust representing Ngāti Toa, made numerous attempts to trade mark Ka Mate. ${ }^{170}$ Their attempts failed as IPONZ held that Ka Mate was widely recognised in New Zealand and internationally as representing New Zealand

160 Earl Gray and Raymond Scott "Rights of attribution for Ka Mate Haka" (2013) 8 JIPLP 200 at 201; and Olsen, above $\mathrm{n} 21$, at 33 .

161 Gray and Scott, above n 160, at 201.

162 Olsen, above n 21, at 34 .

163 At 34 .

164 At 34 .

165 Gray and Scott, above n 160, at 201.

166 At 201

167 At 201

168 At 201.

169 At 201.

170 Te Runanga O Toa Rangatira Inc v Prokiwi International Ltd [2012] NZIPOTM 14 at Schedule 3. 
as a whole, and a single "trader" could not be identified. ${ }^{171}$ Following this, the trade mark applications for "Ka Mate", "upane kaupane", "whiti te ra" and "Ka ora" were denied by the Assistant Commissioner in the case Te Runanga $O$ Toa Rangatira Inc $v$ Prokiwi International Ltd due to the phrases being part of Ka Mate. The Assistant Commissioner stated: ${ }^{172}$

The haka Ka Mate is an important part of New Zealand's heritage, a New Zealand icon, and is a powerful reference to New Zealand, which appears to be largely attributable to its performance by the All Blacks

Rugby Team since 1905 .

This decision reinforced the mainstream perception of Ka Mate, that is a war dance performed by the All Blacks, rather than a significant taonga for Ngāti Toa Rangatira iwi.

Practically, the Haka Ka Mate Attribution Act is unlikely to have any significant commercial implications for businesses. ${ }^{173}$ The attribution aspect is easy to implement so it is to be expected that all persons and businesses who use Ka Mate for commercial purposes will follow the rules set out in the Act. Furthermore, there are no restrictions on the way Ka Mate can be used and Ngāti Toa do not have to give their consent for other parties to use Ka Mate. ${ }^{174}$ This leaves Ka Mate open to the risk of commercial exploitation and offensive usage. ${ }^{175} \mathrm{In}$ the haka misappropriation examples discussed in Part III, the Fiat and BIANZ advertisements used Ka Mate. Both advertisements were released well before the Haka Ka Mate Attribution Act was established but because the Fiat advertisement was created overseas, regardless of whether the Act was in force at that time, Fiat would not have to abide by the provisions of the Act. Consider that the Gingerbread Man advertisement was released after the Act came into force. Would attribution to Te Rauparaha and Ngāti Toa Rangatira be enough to offset the innaporpriate use of Ka Mate in that advertisment? The answer is clearly no. In fact, it is doubtful whether Ngāti Toa Rangatira would even want their name to be associated with a video which shows a total disregard for Ka Mate and mātauranga Māori. What the Act aims to protect and promote attribution to Te Rauparaha and Ngāti Toa Rangatira - is not sufficient in protecting Ka Mate from innapropriate and offensive use. This is a significant weakness of the Haka Ka Mate Attribution Act.

\section{B One Size Does Not Fit All}

Protections for mātauranga Māori do not fit well in New Zealand's current intellectual property regime. This is because this regime, based on a western philospohy of property protection and individual rights, was never intended to protect mātauranga Māori. Currently, trying to protect

171 At Schedule 3.

172 At [48] (footnotes omitted).

173 Gray and Scott, above n 160, at 201.

174 At 202.

175 Olsen, above n 21, at 32 . 
mātauranga Māori using New Zealand's intellectual property laws is like trying to fit the shape of a koru into a square, impossible and culturally impractical. The issues that arise from this are discussed below.

\section{Time requirement}

The New Zealand intellectual property law regime provides only limited protection for mātauranga Māori and taonga works. ${ }^{176}$ One issue arising out of attempting to fit mātauranga Māori into a westernised intellectual property system is the time requirement. The law does not recognise the perpetual nature of the kaitiaki relationship. ${ }^{177}$ Therefore it can be argued that New Zealand's intellectual property law system does not acknowledge kaitiakitanga in respect of mātauranga Māori, ${ }^{178}$ and in turn does not support kaitiaki in their role as guardians of mātauranga Māori. ${ }^{179}$ This becomes apparent when non-kaitiaki use mātauranga Māori in an offensive way, or when non-kaitiaki claim intellectual property rights over taonga works and then proceed to derive cultural and economic benefit from them. ${ }^{180}$ Many features of the intellectual property system such as copyright and trade marks are inadequate in catering for the protection of kaitiaki interests in protecting mātauranga Māori. ${ }^{181}$ For example, copyright protection only lasts 50 years after the creator has passed away, however kaitiakitanga over mātauranga Māori is typically perpetual in nature.

\section{Individual rights}

Mātauranga Māori is difficult to protect using registered intellectual property rights. ${ }^{182}$ For example, in order for a design or patent to be registered or granted it must be new and original. However, inventions or designs that stem from mātauranga Māori have most likely developed over centuries. ${ }^{183}$ Furthermore, intellectual property rights are commonly owned by individuals or a single commercial entity, however, a trait of mātauranga Māori is that it belongs to a collective group. ${ }^{184}$ In te ao Māori, it is common for taonga works to be created by iwi, hapū and whānau groups, rather than by one individual. Typically, taonga works and mātauranga Māori are passed down from generation to generation. The original composer of a haka may have created it centuries ago, but their tūpuna and

176 Ko Aotearoa Tènei: Te Taumata Tuatahi, above n 20, at 39

177 At 39.

178 At 34

179 At 39 .

180 At 34

181 At 34

182 New Zealand Intellectual Property Office, above n 119, at 3.

183 At 3.

184 At 3. 
kaitiaki have carried it through the centuries. Sometimes, the name of the original composer is lost in time. New Zealand's intellectual property system does not provide these kaitiaki with ownership over the haka because technically they are not the original composers, with the exception of Ka Mate and Ngāti Toa.

\section{Inadequate legal framework}

New Zealand's current intellectual property regime is based on European constructs of property, ownership and individualism whereas mātauranga Māori is premised on an entirely contrasting, and at times conflicting, ideological framework. ${ }^{185}$ There are significant differences between the western and Māori view of the ownership of property, including intellectual property, when determining the value of a piece of property and the reward or benefits that should be reaped from its creation. ${ }^{186}$ This results in a clash of principles when mātauranga Māori and the New Zealand intellectual property system attempt to interact. ${ }^{187}$ Māori struggle to meet the western requirements such as individual ownership, originality and time limits on protection. ${ }^{188}$ One example of a negative effect that flows from attempting to fit mātauranga Māori within the European-defined boundaries of the intellectual property system is that once an idea or concept is in the public domain, it can no longer be considered original and so does not qualify for protection. ${ }^{189}$ A lot of mātauranga Māori becomes part of the public domain by default, as it does not meet the westernised requirements for protection, even though it was original knowledge. ${ }^{190}$ Once a work is in the public domain it is free to be used in anyway, including innapropriate and expolitative usage. ${ }^{191}$

Moreover, the law does not safeguard mātauranga Māori from inapproriate or offensive usage by third parties. ${ }^{192}$ Mātauranga Māori and taonga works will only be protected if they meet specific requirements of certain categories of intellectual property law. ${ }^{193}$ And while the physical expression

185 Tania Waikato "He Kaitiaki Mātauranga: Building a Protection Regime for Māori Traditional Knowledge" (2005) 8(2) YBNZ Juris 344 at 347.

186 The Law Library of Congress New Zealand: Māori Culture and Intellectual Property (December 2010) at 4.

187 Waikato, above n 185, at 347 .

188 The Law Library of Congress, above n 186, at 4.

189 Olsen, above n 21, at 21.

190 At 21.

191 At 22.

192 Ko Aotearoa Tēnei: Te Taumata Tuatahi, above n 20, at 39.

193 At 39. 
of some of mātauranga Māori can be protected by copyright, it may be that the underlying ideas, content, or style cannot be copyrighted. ${ }^{194}$

\section{RECOMMENDATIONS FOR EFFECTIVE PROTECTION OF THE HAKA AND MĀTAURANGA MĀORI GENERALLY}

\section{A Domestic Protection}

The signing of the Treaty of Waitangi in 1840 was meant to signify the beginning of two people living side by side in Aotearoa New Zealand. ${ }^{195}$ However, since 1840 the Crown has mainly supported and encouraged Pākehā culture at the expense of Māori, whose culture has been suppressed and neglected. ${ }^{196}$ While the Crown has gradually improved in the way it abides by its Treaty obligations, not enough is being done by the Crown to support Māori and support the thriving of mātauranga Māori. Legislative and policy change is required in order to provide mātauranga Māori with the sufficient protection it requires and deserves. This change will only occur once the Crown changes its mindset, shifting from the old approach which places more value in Pākehā culture to one in which the Crown acknowledges its obligations in fully supporting, promoting and encouraging the flourishing of Māori culture. ${ }^{197}$

Adequate international protection over mātauranga Māori can only be achieved when New Zealand resolves these issues within its own motu (country). Accordingly, this article has a particular focus on establishing a domestic model of protection.

\section{New standards of legal protection}

In the Wai 262 report the Waitangi Tribunal concluded that New Zealand's intellectual property legal framework does not sufficiently protect mātauranga Māori, taonga works and taonga-derived works. ${ }^{198}$ The Tribunal called for the adaption or extension of New Zealand's current intellectual property mechanisms so to provide protection for Māori interests. ${ }^{199}$ The Tribunal put forward two mechanisms of objection: the first was a more general objection mechanism and the second was a mechanism specifically catering to the objections of kaitiaki. Importantly, the Tribunal noted in its report that all existing intellectual property rights in taonga works, taonga derived works and

194 New Zealand Intellectual Property Office, above n 119, at 31

195 Waitangi Tribunal Ko Aotearoa Tēnei: A Report into Claims Concerning New Zealand Law and Policy Affecting Māori Culture and Identity: Te Taumata Tuarua (Wai 262, 2011) vol 2 [Ko Aotearoa Tēnei: Te Taumata Tuarua vol 2] at 699.

196 At 699.

197 At 699

198 At 702

199 At 702 
mātauranga Māori held by individuals would be unaffected, except in the case where the right-holder is using mātauranga Māori, taonga works or taonga derived works in a derogatory or offensive way. ${ }^{200}$

(a) General objection mechanism

Under the general objection mechanism, anyone, not just Māori, may object to offensive public use of taonga works and mātauranga Māori. ${ }^{201}$ The public interest is served by not enforcing any restrictions on who can object under this mechanism. Māori culture is a part of New Zealand culture. Any offensive use of Māori culture has the potential to upset not just kaitiaki and Māori, but also the non-Māori public of New Zealand. For example, when the New Zealand public became aware of a viral video showing an American university football team, the Arizona Wildcats, misusing the haka Ka Mate before their games, there was a large public outcry regarding the inappropriateness of their use, not just from Māori, but from New Zealanders in general. ${ }^{202}$ A petition to stop the Arizona Wildcats from using Ka Mate was created by a Pākehā New Zealand born woman residing in the United States. ${ }^{203}$ The Arizona Wildcats' misuse of Ka Mate trampled on the mana of Ngāti Toa Rangatira and Te Rauparaha. This disregard of mana could be felt by many New Zealanders, even those who did not have a whakapapa (ancestral) connection to Ka Mate, but still regarded and acknowledged Ka Mate as a significant aspect of Māori culture. This example illustrates the need for a platform to be made available to non-Māori and non-kaitiaki New Zealanders where they can express their concerns over offensive usages of taonga works and mātauranga Māori. In this way, the pool of potential complainants is widened which can only be a positive consequence.

(b) Objection mechanism for kaitiaki

The kaitiaki objection mechanism would provide kaitiaki with the ability to make objections to the exploitative commercial use of taonga works and mātauranga Māori. ${ }^{204}$ This mechanism would require a method in determining who is a kaitiaki, and over what taonga. ${ }^{205}$ The Tribunal's recommendation of the establishment of a kaitiaki register would address these concerns. The kaitiaki register is discussed further below.

200 Ko Aotearoa Tēnei: Te Taumata Tuatahi, above n 20, at 52.

201 Ko Aotearoa Tènei: Te Taumata Tuarua vol 2, above n 195, at 703.

202 Neilson, above n 80.

203 Rosanna Price "Petition wants to stop Arizona Wildcats using Ka Mate haka" (1 October 2015) Stuff <www.stuff.co.nz>.

204 Ko Aotearoa Tēnei: Te Taumata Tuarua vol 2, above n 195, at 703.

205 Ko Aotearoa Tēnei: Te Taumata Tuatahi, above n 20, at 53. 


\section{Expert commission}

In its Wai 262 report, the Tribunal acknowledged that New Zealand's intellectual property legal framework, even with adaptions that protect Māori interests, cannot be the sole means of protecting the relationship between kaitiaki and their taonga. ${ }^{206}$ It proposed the establishment of an expert commission to work alongside New Zealand's intellectual property system. It would be the role of this commission to manage, interpret and enforce the new protections described above. ${ }^{207}$ In turn, it would be vital that this commission carry specific adjudicative, facilitative and administrative functions to be able to sufficiently and effectively carry out the mahi that will be required.

This commission would work on an objection-based, case by case basis, and would have the authority to prioritise kaitiaki interests in certain circumstances. ${ }^{208}$ It would be made up of experts in mātauranga Māori, intellectual property law, commerce, science and guardianship of taonga works. ${ }^{209}$ The commission's main kaupapa would include preventing any offensive use of mātauranga Māori, taonga works, or taonga-derived works, and offering an effective and practical way for businesses who want to use an aspect of mātauranga Māori for a commercial purpose to consult with, and seek consent from, the relevant kaitiaki. ${ }^{210}$

(a) Facilitative function

The commission would become the first port of call for prospective users. ${ }^{211}$ Therefore, educating prospective users of taonga works, taonga derived works and mātauranga Māori and facilitating early consultation between users and kaitiaki would be important functions of this commission. ${ }^{212}$ Education and facilitation in this way could be achieved by the commission making available a set of best practice guidelines for the use, care, protection and custody of taonga works, taonga derived works and mātauranga Māori, ${ }^{213}$ making declaratory rulings when required and developing and maintaining a register of kaitiaki interests over particular mātauranga Māori and taonga. ${ }^{214}$

206 Ko Aotearoa Tēnei: Te Taumata Tuarua vol 2, above n 195, at 702.

207 Ko Aotearoa Tènei: Te Taumata Tuatahi, above n 20, at 52.

208 Ko Aotearoa Tènei: Te Taumata Tuarua vol 2, above n 195, at 702.

209 At 702.

210 At 702 .

211 At 702 .

212 At 702 .

213 Ko Aotearoa Tēnei: Te Taumata Tuatahi, above n 20, at 52.

214 Ko Aotearoa Tēnei: Te Taumata Tuarua vol 2, above n 195, at 702. 
Best practice guidelines would assist potential users in gaining an understanding of the significance behind the mātauranga Māori within the work they are wanting to utilise. ${ }^{215}$ These guidelines would also inform potential users of the culturally appropriate practices that should be followed when using a specific taonga or aspect of mātauranga Māori. ${ }^{216}$

Declaratory rulings would serve the purpose of informing an unsure individual on whether their proposed use of a taonga work or aspect of mātauranga Māori is permissible, offensive or infringed on the rights of a kaitiaki. ${ }^{217}$ This would provide certainty at an early stage to prevent a situation where an individual is unsure of, or oblivious to, the offensive or derogatory nature of their claim to ownership. The Tribunal states that this procedure should be quick, informal and inexpensive. ${ }^{218}$

(b) Adjudicative Function

In situations where kaitiaki and potential users cannot come to an agreement and early certainty cannot be achieved, the commission's adjudicating function would be utilised. ${ }^{219}$ The specific expertise of the members of the commission would make it the preferred arena for disputes as opposed to the courts. Typically, the courts lack the required knowledge and experience in mātauranga Māori and tikanga Māori necessary to make the rulings proposed by the new standards of protection. ${ }^{220}$ Here, the commission would balance kaitiaki interests, prospective user interests and the interests of the wider community in a transparent way to determine what level of protection should be given to kaitiaki. ${ }^{221}$ In making their decision, the commission would hear from kaitiaki who would need to prove their kaitiaki status, and provide the opportunity for others to challenge this status. ${ }^{222}$ Any decision made by the commission should be enforceable in the courts. ${ }^{223}$

Furthermore, the Tribunal recommended that this commission should replace the existing Māori Trade Marks Committee. Unlike the Māori Trade Marks Committee who can only provide nonbinding advice to the Commissioner, the decisions of this new committee should be binding. ${ }^{224}$ Regarding the relationship between the commission and the Commissioner, the Tribunal envisaged a

215 Ko Aotearoa Tènei: Te Taumata Tuatahi, above n 20, at 53.

216 At 53 .

217 At 93.

218 At 93.

219 Ko Aotearoa Tènei: Te Taumata Tuarua vol 2, above n 195, at 702.

220 Ko Aotearoa Tēnei: Te Taumata Tuatahi, above n 20, at 52.

221 Ko Aotearoa Tēnei: Te Taumata Tuarua vol 2, above n 195, at 702-703.

222 At 703

223 At 703

224 At 703 
process where any trade mark or patent application involving an aspect of mātauranga Māori that was provided to the Commissioner would then be referred to the commission. ${ }^{225}$

(c) Administrative function

This function of the commission would involve the management and operation of a kaitiaki register. The Tribunal recommended that a kaitiaki register be established where kaitiaki are able to apply to be recorded on the register for a particular taonga or aspect of mātauranga Māori that is already in the public domain. ${ }^{226}$ This would include the registering of haka, waiata, carving, painting and so on. ${ }^{227}$ For taonga and mātauranga Māori that are secret, the Tribunal recommends that they and their kaitiaki should remain secret and not be registered, as secrecy is their best mode of protection. $^{228}$

This register would not just acknowledge individuals as kaitiaki, but also wider whānau, hapū and iwi groups. ${ }^{229}$ In this way, the kaitiaki register would be more in line with the Māori view of guardianship by allowing taonga to be owned, or more appropriately, protected, by a group of people, rather than providing ownership rights to just one individual, as typical under the western ideology of ownership. In the interest of public interest and transparency, there would be a process of public notification to provide for opportunities to object. If no objections arose in a particular case then the kaitiaki would be registered as of right for the taonga or aspect of mātauranga Māori. ${ }^{230}$ Depending on the kaitiaki relationship, that right has the potential to be perpetual in nature. ${ }^{231}$ The fact that a certain taonga or aspect of mātauranga Māori has not been registered will not prevent the relevant kaitiaki from being able to object to an existing or proposed exploitative commercial use of a taonga or mātauranga Māori. This ensures equality between kaitiaki who have registered their interest and kaitiaki who prefer not to publish their relationship with a taonga or aspect of mātauranga Māori. ${ }^{232}$

The key risk attached to the creation of a kaitiaki register is the possibility of conflict between different Māori individuals or groups who all claim that they have interests in a taonga or aspect of mātauranga Māori. ${ }^{233}$ The Tribunal recommends that competing claims should be dealt with on a case

225 Ko Aotearoa Tēnei: Te Taumata Tuatahi, above n 20, at 53.

226 At 54

227 At 54 .

228 At 54 .

229 At 54

230 At 54

231 At 92

232 At 54.

233 Seamus Woods "Patents, PVRS and Pragmatism: Giving Effect of Wai 262" (2013) 19 Canta LR 97 at 117. 
by case basis, but provides little detail on how these disputes would be settled. The best way to approach these types of issues would be to use tikanga Māori to establish the rightful kaitiaki by applying tikanga principles to identify which individual or group has the strongest connection to the taonga or aspect of mātauranga Māori in dispute. While following tikanga principles may not always solve the dispute completely, it is a valuable starting point. ${ }^{234}$

The Waitangi Tribunal's recommendations are reasonable, achievable and beneficial to the thriving of mātauranga Māori. One of the more notable consequences that stem from these recommendations is the emphasis and importance placed on the role of the kaitiaki. If these recommendations were implemented, it would provide sufficient protection against the derogatory or offensive use of taonga and mātauranga Māori, such as haka, within New Zealand. Furthermore, by giving potential users early certainty and by acknowledging that the kaitiaki interest will not always trump others, the interests of all parties will be balanced in a way that is ethical and transparent. ${ }^{235}$ The Waitangi Tribunal stressed that their recommendations do not conflict with New Zealand's current intellectual property law system as they are sui generis and are expressly concerned with the Treaty obligation to protect tino rangatiratanga (control) over taonga and mātauranga Māori, ${ }^{236}$ and so would operate outside the existing framework. Therefore the implementation of the recommendations should not result in any irreparable friction with the current laws in force.

While the implementation of domestic laws that protect taonga and mātauranga Māori would be a positive step forward, these laws would do nothing to protect taonga and mātauranga Māori from being misappropriated overseas. The next section will discuss the possibilities of international protection for taonga and mātauranga Māori.

\section{B International Protection}

In order to protect mātauranga Māori on a global stage, legal norms offering positive protection for indigenous peoples' traditional knowledge are essential. ${ }^{237}$ The development of these norms is an ongoing process for the WIPO-IGC.

The WIPO-IGC has been drafting a legal instrument to protect traditional cultural expressions since 2000. The negotiations are long and this can be attributed to the complexity of multilateral

\section{At 118}

235 Ko Aotearoa Tēnei: Te Taumata Tuarua vol 2, above n 195, at 702.

236 Jessica Christine Lai Māori Traditional Cultural Expressions and the Wai 262 Report: Looking at the Details (Working Paper No 2012/02, University of Lucerne, 2012) at 19.

237 Sue Noe and Melody McCoy "World Intellectual Property Organization Instruments on Traditional Knowledge, Genetic Resources, and Traditional Cultural Expressions" Native American Rights Fund <www.narf.org/cases/wipo>. 
negotiations, which require the input and consideration of various member states to ensure all traditional cultural expressions are sufficiently protected under the proposed international instrument.

When this instrument is finalised it will provide transnational protection for cultural traditional expressions, meaning aspects of mātauranga Māori, such as the haka, will have protection in states that have ratified or acceded to the instrument. ${ }^{238}$ This would be a significant step towards global protection of mātauranga Māori and may prevent misappropriation incidents that occur overseas such as the Fiat and Heineken advertisements discussed at Part III. However, a limitation of this instrument is that it can only be enforced in the states that have ratified or acceded to it. States who are resistant to providing adequate protections for their own indigenous culture are unlikely to accede to this instrument and therefore will not be bound by the transnational laws the instrument will enforce. Nevertheless, transnational laws among states who accede to this instrument will be better than the protection currently available on an international level. When the negotiations regarding this instrument are complete, New Zealand should ratify and accede to the instrument that is established. In the meantime, New Zealand should engage in discussions with the WIPO-IGC to ensure that the proposed instrument will provide sufficient international protection for mātauranga Māori.

\section{CONCLUSION}

Since the signing of the Treaty of Waitangi in 1840 Māori and their culture have been supressed and neglected both in societal and legal realms. One consequence of this is that New Zealand's intellectual property law system does not protect mātauranga Māori against derogatory and offensive use both within New Zealand and on an international stage. This is because mātauranga Māori was never intended to fit within the boundaries of intellectual property. ${ }^{239}$ Tania Waikato notes, "mātauranga [Māori] is now exposed to exploitation, because the laws that did not account for it are now responsible for its protection". 240

As illustrated in the misappropriation examples in Part III, aspects of mātauranga Māori, such as the haka, have been commercially exploited by businesses who fail to understand and acknowledge the significance and tapu nature of taonga and mātauranga Māori. These businesses are allowed to do this because currently there is no law that prohibits this kind of activity.

New Zealand's current intellectual property framework has limitations that render it almost useless in protecting taonga and mātauranga Māori. These limitations include the time requirement and its use of European constructs of property, ownership and individualism. One law exists in New Zealand

238 Wend Wendland "Multilateral Matters \#3: Copyrighting Culture? Challenges and opportunities regarding the international protection of traditional cultural expressions" University of Cape Town Intellectual Property Unit <http://ip-unit.org>.

239 Waikato, above n 185 , at 347.

240 At 347. 
that attempts to protect a haka, the Haka Ka Mate Attribution Act. This law requires anyone who wants to use Ka Mate in a commercial endeavour to attribute it to its kaitiaki, Ngāti Toa Rangatira, and its creator, Te Rauparaha. While this Act is a step in the right direction, it does not protect Ka Mate from being misappropriated in New Zealand. Moreover, this Act has no authority overseas. Accordingly, it does not provide sufficient protection for Ka Mate.

New Zealand should take a leading role on the international stage by developing a domestic framework that provides sufficient protection for taonga and mātauranga Māori. ${ }^{241}$ The adoption of the Waitangi Tribunals's recommendations set out in the Wai 262 report would achieve this. These recommendations include the establishment of an expert commission to work alongside New Zealand's intellectual property system. This commission would manage, interpret and enforce the new standards of legal protection that the Waitangi Tribunal also recommended in the Wai 262 report, those being two mechanisms that would provide a platform for individuals to object to the offensive public and commercial use of taonga and mātauranga Māori. The Waitangi Tribunal's recommendation of establishing a kaitiaki register would be a significant aspect of the protection of mātauranga Māori. This register would acknowledge kaitiaki as the guardians over their respective taonga in law, providing kaitiaki with a means to enforce their kaitiakitanga against third parties. The relationship between kaitiaki and taonga is precious to Māori and affirming this relationship in law would adhere to the Crown's obligations under the Treaty of Waitangi.

Regardless of whether the New Zealand Government adopts the recommendations of the Waitangi Tribunal, taonga and mātauranga Māori remain vulnerable to derogatory and offensive use overseas. When the WIPO-IGC completes its negotiations regarding the traditional cultural expressions protection instrument, New Zealand should ratify and accede to this instrument so to extend protection of mātauranga Māori into the international sphere.

The Government's 2019 announcement and release of Te Pae Tawhiti is a welcome and longawaited response to the inadequacies in New Zealand's intellectual property law framework, as identified in the Wai 262 report. Te Pae Tawhiti is still at a preliminary stage with consultation with Māori taking place in late 2019. Time will tell whether Te Pae Tawhiti and the mahi that follows will improve the legal protections over mātauranga Māori in New Zealand and overseas. Nevertheless, the release of this whole of government approach is a promising milestone because I orea te tuatara ka patu ki waho, a problem is solved by continuing to find solutions. ${ }^{242}$

241 Ko Aotearoa Tēnei: Te Taumata Tuatahi, above n 20, at 56.

242 "Māori Proverbs" (14 August 2018) Massey University <www.massey.ac.nz/massey/maori/resources>. 